\title{
Spatial distribution of coffee crop productivity in Minas Gerais over time
}

\author{
Renan Serenini ${ }^{1}$, Patrícia de Siqueira Ramos ${ }^{2}$, Lincoln Frias ${ }^{3}$
}

DOI: https://doi.org/10.35699/2447-6218.2020.26171

\begin{abstract}
Brazil is the world's largest coffee producer and the state of Minas Gerais is responsible for half of the Brazilian production. However, productivity is unevenly distributed throughout the state. Therefore, the purpose of this study is to analyze the spatial distribution of coffee productivity in Minas Gerais from 2002 to 2017, a valuable information to identify regions where coffee production may be more promising in the future. This paper investigates the existence of spatial dependence of productivity between regions (using Moran's $I$ ), its dynamics throughout the period and the presence of clusters of high and low productivity (using local Moran's I). The results show that the spatial dependence of productivity was stronger from 2002 to 2009 than between 2010 and 2017. Some regions with small coffee areas but high productivity have stopped producing the crop whereas some of those with large areas but low productivity increased their productivity levels. Therefore, there is a tendency of homogenization of productivity in Minas Gerais, with values close to 30 bags per hectare.
\end{abstract}

Key-words Moran's I. Spatial autocorrelation. Spatial Statistics.

\section{Distribuição espacial da produtividade de café em Minas Gerais ao longo do tempo}

\section{Resumo}

O Brasil é o maior produtor mundial de café e o estado de Minas Gerais é responsável por metade da produção brasileira. Entretanto, a produtividade é distribuída de forma desigual no estado. Assim, o objetivo deste estudo é analisar a distribuição espacial da produtividade de café em Minas Gerais entre 2002 e 2017, uma informação valiosa para identificar regiões em que a produção de café possa ser mais promissora no futuro. O artigo em questão investiga a existência de dependência espacial na produtividade entre regiões (usando o I de Moran), a dinâmica ao longo do período estudado e a presença de agrupamentos de alta e baixa produtividade (usando o I de Moran local). Os resultados mostram que a dependência espacial era mais forte de 2002 a 2009 do que entre 2010 e 2017. Algumas regiões com pequenas áreas de plantio de café mas com alta produtividade deixaram de produzir enquanto regiões com grandes áreas mas baixa produtividade aumentaram seus níveis de produtividade. Assim, existe uma tendência de homogeneização da produtividade em Minas Gerais, com valores em torno de 30 sacas por hectare.

Palavras-chave: Autocorrelação espacial. Estatística Espacial. I de Moran.

\footnotetext{
${ }^{1}$ Sapienza University of Rome. Rome, Italy. https://orcid.org/0000-0001-7757-0034

${ }^{2}$ Universidade Federal de Alfenas. Varginha, MG. Brasil. https://orcid.org/0000-0003-4834-661X

${ }^{3}$ Universidade Federal de Alfenas. Varginha, MG. Brasil. https://orcid.org/0000-0001-9474-6441

*Autor para correspondência: renan_serenini@hotmail.com
}

Recebido para publicação em 10 de novembro de 2020. Aceito para publicação em 11 de dezembro de 2020. e-ISSN: 2447-6218 / ISSN: 2447-6218. Atribuição CC BY. 


\section{Introduction}

In 2017, Brazil produced $32 \%$ of all the world's coffee, thus being the largest producer of this crop according to the International Coffee Organization (ICO, 2018). In that year, the state of Minas Gerais was responsible for $53 \%$ of the Brazilian production (CONAB, 2018). Therefore, the study of coffee production in this state is fundamental to understand coffee production in general.

Neither production nor productivity are evenly distributed throughout the state. This is a recurring phenomenon in agriculture, given that the development of agricultural crops relies on factors that vary spatially. These include both natural factors (soil fertility, temperature, rainfall etc.) as well as logistic factors (roads, warehouses, access to technical assistance, cost of inputs, competition with other crops etc.) (Teixeira; Bertella, 2015; Souza; Perobelli, 2007).

In view of this, the purpose of this paper is to analyze the dynamics of the spatial distribution of coffee productivity in Minas Gerais from 2002 to 2017. The aim is to verify whether coffee productivity is randomly distributed in the state or whether there are patterns of spatial distribution of regions with similar levels of productivity. For example, the most efficient regions may tend to be concentrated in the south of the state. The paper also describes how this spatial distribution changed over time, identifying regions which increased or decreased their productivity levels.

This kind of information is useful in identifying the most promising areas for coffee production. Also, it could help in the improvement of the official harvest forecasts (Neves; Luiz, 2006). The Companhia Nacional de Abastecimento (CONAB) monitors the Brazilian coffee crops, publishing regular forecasts of harvested area, production and productivity, using, among other methods, satellite images of statistically selected regions (CONAB, 2018). The results of the spatial analysis are helpful in the sampling design of those regions.

The innovative contribution of this work is twofold. In contrast to previous studies, to be summarized in the next section, this paper examines all the years from 2002 to 2017, not only two or three points in time. Secondly, it employs the new Brazilian regional division, published by the Brazilian Institute of Geography and Statistics (Instituto Brasileiro de Geografia e Estatística, IBGE) in 2017. This revised division improves the old micro and mesoregions division by taking into account the urban network and the management flows. The incorporation of this new and more rigorous division in the spatial analysis may reveal patterns previously masked.

Spatial analysis has been widely used in studies of crop production and productivity. Souza and Perobelli (2007) examined the spatial distribution of coffee pro- ductivity in the 558 Brazilian microregions in 1991, 1997 and 2003. The values of Moran's $I$ were 0.30 in 1991 , 0.34 in 1997 and again 0.34 in 2003, always statistically significant. Therefore, the authors confirmed the existence of positive spatial correlation, persisting throughout the studied period.

Almeida et al. (2006) examined the spatial distribution of the coffee productivity in Minas Gerais for the years 2000 and 2004 taking as units the 66 microregions of the state. Productivity was measured as the ratio between the sum of the production of all the cities in the microregion and its total harvested area. The study not only found spatial autocorrelation in coffee productivity in both years but also that it increased between them, as the Moran's I went from 0.24 in 2000 to 0.32 in 2004. The clusters with higher productivity were located in the northwestern region of the state. According to the authors, the rising concentration suggests that higher productivity could be influencing the emergence of regions of equal performance in their neighborhood.

The remainder of this paper is organized as follows. Section 2 presents the dataset, the kind of geographic units under study and the central concepts in exploratory spatial data analysis. Section 3 contains the results and discussion of both the descriptive and the spatial analysis. Finally, some concluding remarks are given in Section 4.

\section{Materials and methods}

This study uses data from the Municipal Agricultural Production (Produção Agrícola Municipal, PAM) survey (IBGE, 2019), ranging from 2002 to 2017. The data begins in 2002 because this is the year when coffee measuring unit changed from dry cherry coffee (café em côco) to processed coffee or coffee beans (café beneficiado ou em grão). The data is available through IBGE System of Automatic Recovery System (SIDRA), table 1613 ("Area to be harvested, harvested area, quantity produced, average productivity and production value of permanent crops").

In this study, productivity is specified as the ratio between the total production volume (in 60kg bags) and the total area harvested (in hectares) in a certain year. High productivity regions are those that produce more than 25 bags per hectare $(1,500 \mathrm{~kg})$, the median value among the immediate geographic regions 2017.

In 2017, from the 853 Minas Gerais municipalities, 354 (42\%) did not produce coffee. A variable with a great number of zeros creates some problems for the spatial analysis. Thus, instead of municipalities, the adopted unit of analysis are the immediate geographic regions, the updated equivalent of microregions. Considering the 70 immediate geographic regions in the state, only 7 did not produce coffee. 
The division of Brazilian states into mesoregions and microregions was used by IBGE from 1989 to 2017. IBGE published in 2017 a new framework for the regional division of Brazil, rearranging the former mesoregions and microregions into intermediate and immediate geographical regions, respectively (IBGE, 2017). Comparing the two divisions, Minas Gerais has 12 mesoregions, but 13 intermediate regions and, at the lower level, to the 66 microregions correspond 70 immediate regions.

Exploratory spatial data analysis is the set of techniques used to describe and examine spatial data (Anselin, 1996). The central problem in this kind of study is to check whether or not the data is randomly distributed in space. In this context, the opposite of randomness is spatial dependence (or spatial autocorrelation) between the observations, meaning that neighboring regions are more closely associated with each other regarding the value of a determined variable than with distant regions, either positively or negatively.

The fundamental statistics in an exploratory spatial data analysis are global and local autocorrelation. The first requirement in their calculation is the definition of a spatial weights matrix (W) (Almeida, 2012). This is a $n$-square matrix whose elements denote the spatial connection (neighborhood) between the regions according to some criterion of proximity, such as contiguity or distance, representing for each $i$ region its spatial relationship to each other region $j$. The present paper uses contiguity as the proximity criterion. In this case, the matrix element $\mathrm{w}_{\mathrm{ij}}$ has value 1 when the regions share a border and 0 otherwise. This paper adopts the queen criterion of contiguity, which defines as contiguous all spatial units sharing a boundary, in any direction, with the region in focus (Almeida, 2012).

\section{Results and discussion}

In 2002, 21.68 million bags of coffee were produced on 1.09 million hectares, resulting in 19.9 bags per hectare. In 2017, 24.25 million bags were produced in 925 thousand hectares, resulting in a productivity of 26.2 bags per hectare. The increase in production $(11.9 \%$ from 2002 to 2017) was, in relative terms, slightly less relevant for the increase in productivity than the reduction of the area (15.1\% from 2002 to 2017).

Coffee productivity in the state has increased over time, representing an improvement in efficiency in coffee production, measured as the division of the production in the state by the area harvested in each year. In 2002, the average production was 20 bags per hectare, whereas in 2016, the last year with positive biannuality, $29.4 \mathrm{bags} / \mathrm{ha}$ were produced (in 2017, 26.2 bags/ha). The increase in productivity was not only due to a reduction in harvested area (keeping production constant) or an increase in production (keeping harvested area constant), but rather a consequence of both factors: increased production and reduced harvested area throughout the state of Minas Gerais.

Moving from the entire state of Minas Gerais to its subdivisions, Table 1 gives an overview of the distribution of the harvested area, production and productivity among the 70 immediate geographic regions of Minas Gerais in 2002, 2010 and 2017.

Table 1 - Descriptive statistics of harvested area, production and productivity of the immediate geographic regions of Minas Gerais (2002, 2010 e 2017)

\begin{tabular}{ccccc}
\hline year & mean & standard deviation & minimum & maximum \\
\hline 2002 & $15,522.4$ & harvested area (ha) & & \\
2010 & $14,665.9$ & $22,694.1$ & 0.0 & $115,949.0$ \\
2017 & $13,215.8$ & $21,564.9$ & 0.0 & $117,440.0$ \\
& & $21,693.1$ & 0.0 & $121,277.0$ \\
2002 & $309,768.8$ & production (bags) & & \\
2010 & $358,140.0$ & $483,054.0$ & 0.0 & $2,419,200.0$ \\
2017 & $346,376.0$ & $560,156.9$ & 0.0 & $2,756,133.3$ \\
& & $548,525.4$ & 0.0 & $2,648,583.3$ \\
2002 & 17.1 & productivity (bags/ha) & & \\
2010 & 21.8 & 9.0 & 0.0 & 47.8 \\
2017 & 23.0 & 11.6 & 0.0 & 64.5 \\
\hline
\end{tabular}

Source: Prepared by the authors based on data from the Produção Agrícola Municipal (IBGE, 2019). 
Serenini, R. et al.

The average harvested area decreased 15\% from 2002 to 2017 . On the other hand, the average production increased $12 \%$ in the same period. The minimum value of both harvested area and production has remained at zero since at least one region did not produce coffee in each one of the years. The maximum value of harvested area had a slight increase. However, production decreased from 2010 to 2017.

Despite this recent fall in production, average productivity shown a steady increase. In 2010, a reduced harvested area and a larger production improved productivity from 17.1 to 21.8 bags per hectare. A new increase, although smaller, was seen in 2017 as average productivity reached 23 bags per hectare. So, whereas the first period saw a $27 \%$ improvement, it represented only $5,5 \%$ in the second period.

In 2017, the distribution of productivity among the immediate regions was as follows: $25 \%$ of the regions had productivity of up to 18 bags/ha, $50 \%$ up to 24.7 bags/ha and $75 \%$ up to 29.7 bags per hectare.

To begin to understand the spatial dimension of the data, Figure 2 includes choropleth maps of coffee productivity by immediate region in Minas Gerais from 2002 to 2017. These kind of maps, also called thematic maps, color the region according to the level of the variable under study. In the present case, the threshold values of productivity was based on 2017 data, the last of the series, selecting the values which divided the observations into six quantiles of approximately equal sizes (containing 11 or 12 observations each).

According to Figure 1, the spatial pattern of productivity per region has changed over time. In the early years, few regions had average productivity above 25 bags per hectare and they were predominantly located in the north and northwest of Minas Gerais, more specifically in the regions of Montes Claros and Patos de Minas. In the following years, other regions began also to show higher levels of productivity, resulting in a more dispersed distribution of regions with high productivity throughout the territory.

Table 2 shows the evolution of the number of immediate regions in the high productivity group in each intermediate region in the years under consideration, whereas Table 3 shows the number of immediate regions in each reference interval by year.

The spread of high productivity among the intermediate regions is evident in Table 2. In 2002, of the 13 intermediate regions, only 4 contained any immediate regions of high productivity. In the following years, a steady increase was observed: 8 in 2006, 9 in 2010, 10 in 2013, and 12 in 2017. Thus, in the final year of the series, of the 13 intermediate regions, only one (Ipatinga) did not contain any immediate region with high productivity.

Table 3 shows in greater detail how the number of immediate regions in each productivity interval (the same used in Figure 2) changed by year. An impressive increase was observed in the higher intervals (fourth, fifth and sixth), that together compose what this paper has been calling high productivity. From 2002 to 2017, the number of regions in the fourth interval (between 25 and 29 bags/ha) went from 2 to 13, while in the fifth interval (between 29 and 33 bags/ha) it went from 4 to 9. Finally, the number of regions producing over 33 bags/ha went from 5 in 2002 to 12 in 2017.

Therefore, there was a steady spreading of productivity throughout the state. In addition, this occurred by increasing the productivity level of regions with lower levels while generally maintaining the levels of those regions that were already at the higher levels. In this way, coffee productivity became more homogeneous in the state of Minas Gerais.

It is possible that this spreading process has as one of its main determining factors the contiguity (the sharing of a border) to a region that already had high levels of productivity. As can be seen in Figure 2, each year many of the regions that showed higher productivity for the first time were the neighbors of those that already were in that condition, generating a spreading effect of high productivity throughout the state.

The following paragraphs describe how high coffee productivity spread among the immediate regions of Minas Gerais from 2002 to 2017, stressing the role of contiguity. This movement is also described on the upper geographic level, that of intermediate regions.

In 2002, of the 70 immediate regions of Minas Gerais (the old microregions), only 8 showed high productivity. These regions were distributed in only 4 intermediate regions of the 13 that compose the state (the old mesoregions). Four immediate regions were in the intermediate region of Montes Claros (Salinas, Pirapora, Espinosa and São Francisco), two in the region of Patos de Minas (Patos de Minas and Unaí), one in Uberlândia (Uberlândia) and one in Uberaba (Araxá).

In 2006, the number of immediate regions with high productivity increased from 8 to 15 . Of the 8 regions that were at that level in 2002, six remained, and two left, Espinosa and Araxá. In addition to these six, 9 other regions joined the group. Of the nine, five were neighbors of regions that already had high productivity: Janaúba (neighbor of Salinas and Espinosa), Curvelo (neighbor of Pirapora), Dores do Indaiá (neighbor of Patos de Minas and Araxá), Abaeté (neighbor of Patos de Minas) and Monte Carmelo (neighbor of Uberlândia and Araxá). 
Figure 1 - Coffee productivity in the immediate geographic regions of Minas Gerais, 2002 to 2017

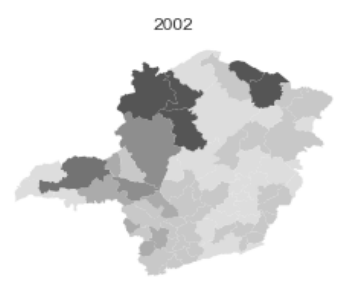

2005

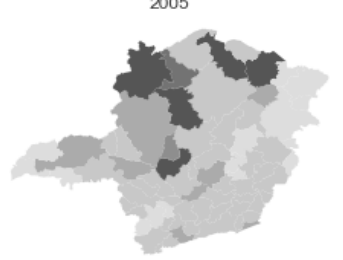

2008

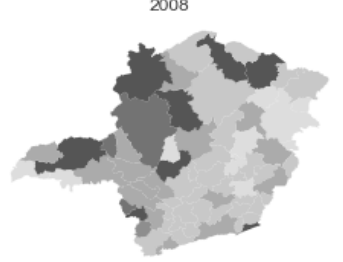

2011


2017

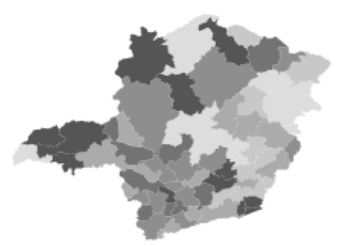

2003


2015
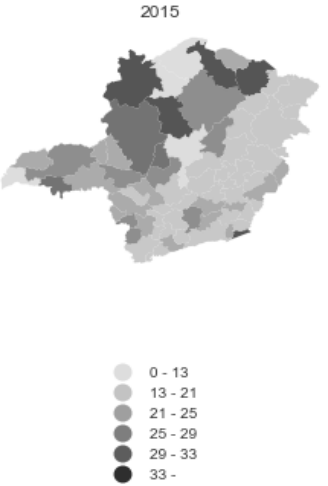

2004

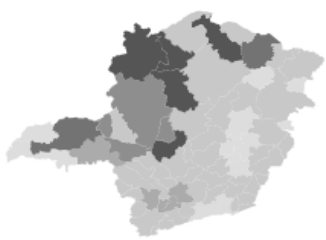

2007



2010



2013
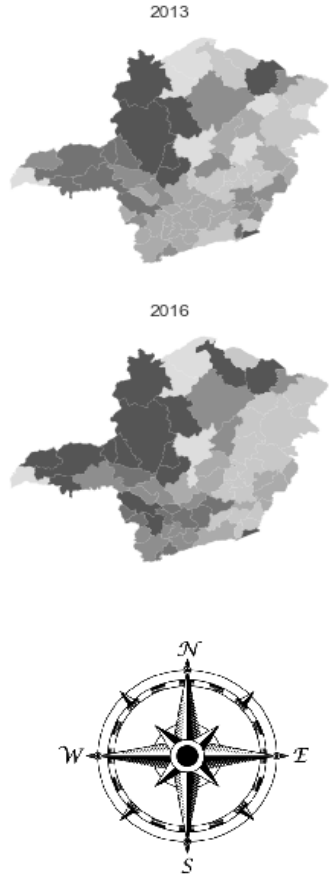

Source: Prepared by the authors based on data from the Produção Agrícola Municipal (IBGE, 2019).

Concerning the upper geographical level (the intermediate regions, the equivalent of mesorregions), if in 2002 only four of them contained immediate regions of high productivity, in 2006 this number had doubled. The intermediate region of Montes Claros had four immediate regions with high productivity, while each of the regions of Belo Horizonte, Patos de Minas, Uberlândia, and Divinópolis comprised two immediate regions in this situation and the regions of Varginha, Pouso Alegre and Juiz de Fora contained only one each.
Returning to the level of the immediate regions, in 2010, once again there was an increase in the number of regions with high coffee productivity (fourth, fifth and sixth reference ranges shown on the maps), from 15 to 21 . Of the fifteen immediate regions of 2006 in this situation, ten remained. Of the eleven that became highly productive (Araxá, which was already in the group in 2002, returned), eight were neighbors of regions that already had high productivity in 2006 and/or 2002. Exceptions are the immediate regions of Poços de Caldas, Alfenas and São João del Rei, which were not neighbors of highly productive regions. 
Serenini, R. et al.

Table 2 - Number of immediate geographic regions with high productivity (above 25 bags/ha) by intermediate region

\begin{tabular}{lccccc}
\hline Intermediate Region & $\mathbf{2 0 0 2}$ & $\mathbf{2 0 0 6}$ & $\mathbf{2 0 1 0}$ & $\mathbf{2 0 1 3}$ & $\mathbf{2 0 1 7}$ \\
\hline Barbacena & 0 & 0 & 1 & 0 & 2 \\
Belo Horizonte & 0 & 2 & 0 & 1 & 2 \\
Divinópolis & 0 & 2 & 2 & 3 & 3 \\
Governador Valadares & 0 & 0 & 0 & 0 & 1 \\
Ipatinga & 0 & 0 & 0 & 0 & 0 \\
Juiz de Fora & 0 & 1 & 1 & 6 & 3 \\
Montes Claros & 4 & 3 & 3 & 3 & 4 \\
Patos de Minas & 2 & 3 & 3 & 3 & 2 \\
Pouso Alegre & 0 & 1 & 1 & 1 & 3 \\
Teófilo Otoni & 0 & 0 & 0 & 1 & 1 \\
Uberaba & 1 & 0 & 2 & 3 & 3 \\
Uberlândia & 1 & 2 & 3 & 3 & 8 \\
Varginha & 0 & 1 & 5 & 21 & 34 \\
Total & 8 & 15 & & & 3 \\
\hline
\end{tabular}

Source: Prepared by the authors based on data from the Produção Agrícola Municipal (IBGE, 2019).

Table 3 - Number of immediate geographic regions in each reference interval per year

\begin{tabular}{lccccccc}
\hline Year & $\begin{array}{c}\mathbf{0 - 1 3} \\
\text { bags/ha }\end{array}$ & $\begin{array}{c}\mathbf{1 3 - 2 1} \\
\text { bags/ha }\end{array}$ & $\begin{array}{c}\mathbf{2 1 - 2 5} \\
\text { bags/ha }\end{array}$ & $\begin{array}{c}\mathbf{2 5 - 2 9} \\
\text { bags/ha }\end{array}$ & $\begin{array}{c}\mathbf{2 9 - 3 3} \\
\text { bags/ha }\end{array}$ & $\begin{array}{c}\text { > 33 } \\
\text { bags/ha }\end{array}$ & $\begin{array}{c}\text { Highly productive } \\
\text { (> 25 bags/ha) }\end{array}$ \\
\hline 2002 & 24 & 32 & 6 & 2 & 1 & 5 & 8 \\
2006 & 13 & 29 & 13 & 5 & 5 & 5 & 15 \\
2010 & 9 & 33 & 7 & 9 & 1 & 11 & 21 \\
2013 & 7 & 14 & 23 & 12 & 7 & 7 & 26 \\
2017 & 13 & 10 & 13 & 13 & 9 & 12 & 34 \\
\hline
\end{tabular}

Source: Prepared by the authors based on data from the Produção Agrícola Municipal (IBGE, 2019).

In 2010 , the number of intermediate regions with immediate regions of high productivity increased to 9 , with the inclusion of Barbacena. The 21 highly productive immediate regions were distributed as follows: five in the intermediate region of Varginha, three in the regions of Uberlândia, Patos de Minas and Montes Claros, two in the regions of Uberaba and Divinópolis and one in the regions of Pouso Alegre, Juiz de Fora and Barbacena.

In 2013, the number of immediate regions with high productivity increased again, from 21 to 26 . Of these, fifteen were already in the group in 2010 and one, the immediate region of Abaeté, had already appeared in 2006. Of the other ten, six were neighbors of immediate regions that were in the high productivity group in previous years. Although the other four (Viçosa, Ponte Nova, Manhuaçu and Muriaé) did not share a border with regions that already had high productivity, they are neighbors to each other and belong to the intermediate region of Juiz de Fora, that until then only had the immediate region of Além Paraíba in the high productivity group.

Finally, in 2017, the number of immediate regions in the high productivity group went from 26 to 34 , a remarkable increase when compared to the eight observed in 2002. Among the 34, 17 were in the group in 2013 and six had already been present in one of the other previous years under study, although not in 2013. Of the remaining eleven, seven were neighbors of regions that belonged to the high productivity group in 2013 .

Therefore, the increase in productivity tended to occur in the neighbors of those regions that were already 
highly productive, pointing to the presence of spatial autocorrelation. As mentioned in the previous section, Moran's $I$ is a statistical measure that quantifies this kind of spatial association. Table 4 shows its values for each year in the period under consideration.

It is possible to divide the data on Table 4 into two periods: the first eight years, from 2002 to 2009, and the last eight years, from 2010 to 2017. In the first period, Moran's $I$ was statistically significant at a significance level of $5 \%$ in all years, with a positive sign, indicating the presence of positive autocorrelation between the immediate regions. In other words, there was a tendency of highly productive regions to share some border with other regions in the same situation, the same being applied to those with low productivity.

Table 4 - Spatial autocorrelation (Moran's I) of coffee productivity in immediate geographic regions in Minas Gerais by year

\begin{tabular}{ccc}
\hline Year & Moran's I & p-value \\
\hline 2002 & $0.347^{*}$ & 0.001 \\
2003 & $0.370^{*}$ & 0.001 \\
2004 & $0.304^{*}$ & 0.001 \\
2005 & $0.308^{*}$ & 0.001 \\
2006 & $0.380^{*}$ & 0.001 \\
2007 & $0.202^{*}$ & 0.010 \\
2008 & $0.168^{*}$ & 0.007 \\
2009 & $0.182^{*}$ & 0.015 \\
2010 & 0.097 & 0.086 \\
2011 & $0.132^{*}$ & 0.031 \\
2012 & 0.106 & 0.061 \\
2013 & 0.009 & 0.377 \\
2014 & 0.056 & 0.158 \\
2015 & -0.043 & 0.370 \\
2016 & 0.099 & 0.065 \\
2017 & 0.068 & 0.153 \\
\hline
\end{tabular}

Source: Prepared by the authors based on data from the Produção Agrícola Municipal (IBGE, 2019). Pseudo $p$-value obtained from 999 random permutations.

In the second period, only one year had statistically significant Moran's I, 2011, and even in this case the magnitude was smaller than those observed in the previous period. This means that the spatial dependence of productivity has been reduced over the years due to the spread of productivity throughout the state, with the ensuing greater homogeneity of the regions. This can be checked using Moran's scatterplot for each year, shown in Figure 3. In this kind of plot, with each point representing a region, the horizontal axis represents the value of the variable in that region and the vertical axis represents the spatially lagged variable, that is, its average value in the contiguous regions. The adjustment line slope coefficient corresponds to the value of Moran's $I$.

The scatterplots of the early years show the distinctive pattern of positive autocorrelation, in which most regions are in the high-high and low-low quadrants. In 2002, 57 of the 70 regions were in one of these two quadrants. On the other hand, in the last years the distribution is more homogeneous between the quadrants, with the adjustment line slope becoming flatter.

To determine the presence of spatial clusters and outliers, local Moran's I for each region were calculated. These are local indicators of spatial autocorrelation (LISA) and are the building blocks for the LISA maps, such as those shown in Figure 4. The maps show the names of the immediate regions with significant LISA values at a $5 \%$ level of significance.

Confirming the descriptive and the global analysis, the LISA maps in Figure 3 show a reduction in the significant clusters and outliers over the period under consideration. In the first eight years, large clusters are noticeable, mainly the cluster of high productivity in the Northwest region of Minas Gerais. However, over the following years, this cluster gradually disappeared 
Serenini, R. et al.

in response to two movements: the increase in the productivity of other regions turned the difference between them not statistically significant and the abandonment of coffee production in some regions.

On one hand, some regions with low productivity increased their productivity levels, as exemplified by the largest cluster of low productivity seen over the period. In 2002, there was a low-low cluster consisting of five regions: Santa Bárbara - Ouro Preto, Guanhães, Ipatinga, Itabira and João Monlevade. All of them had productivity below 13 bags/ha. In 2017, of the five regions, three had increased appreciably their productivity levels. Santa Bárbara-Ouro Preto increased productivity by approximately 334\%, Ipatinga, $210 \%$ and Guanhães, 128\%. The other two regions also increased their productivity, but at lower levels, 4 and 15\%.

Figure 2 - Moran's scatterplots for productivity, 2002 to 2017
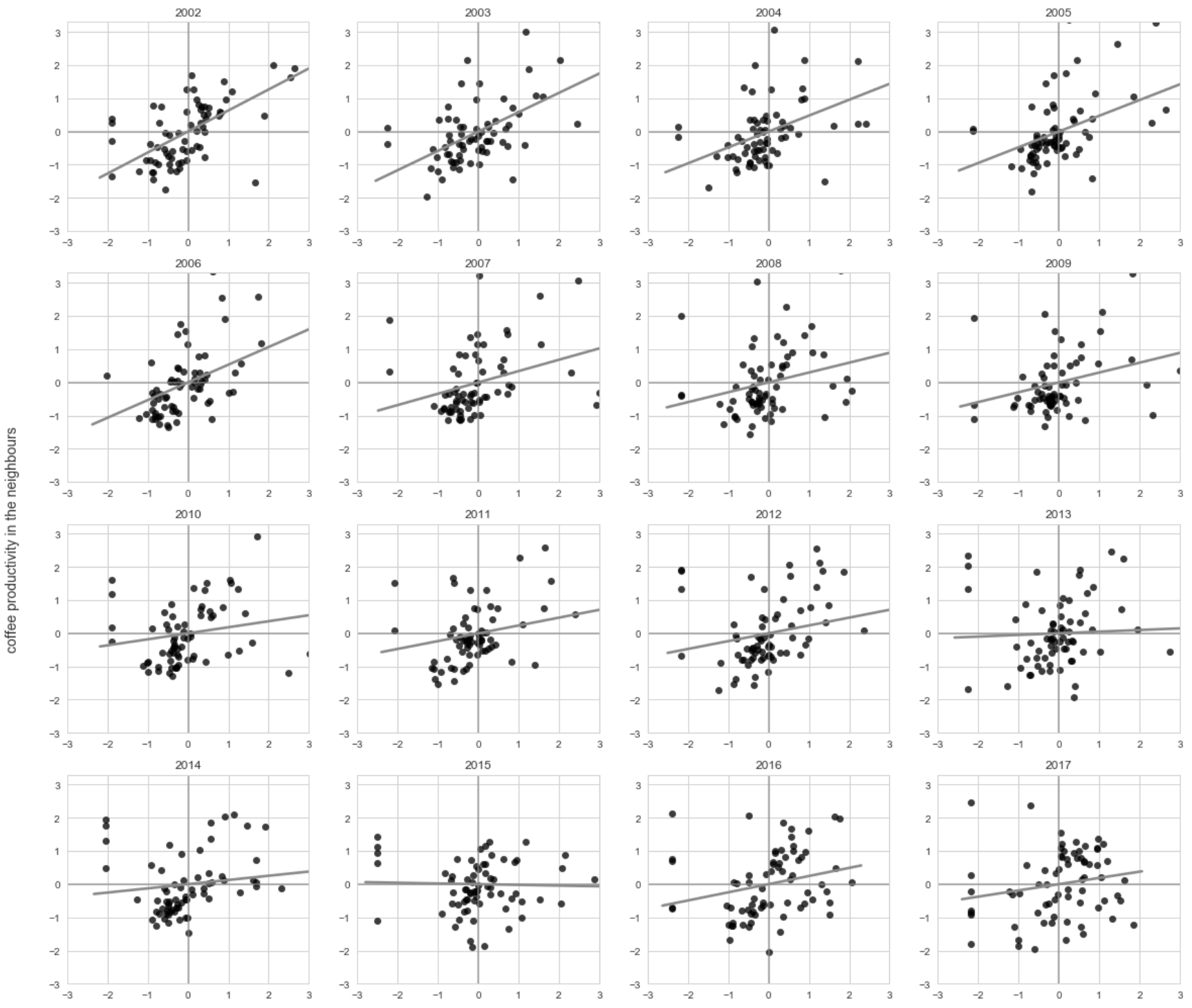

coffee productivity

Source: Prepared by the authors based on data from the Produção Agrícola Municipal (IBGE, 2019).

In 2006, a low-low cluster comprised almost all of the eastern area of the state, composed by 10 immediate regions: Governador Valadares, Guanhães, Ponte Nova, Capelinha, Ipatinga, Almenara, Manhuaçu, Ubá, João Monlevade and Teófilo Otoni. In that year, of these regions only two had productivity above 16 bags/ha. Nonetheless, in 2017, the situation was reversed: only two of the same ten regions had productivity below 16 bags per hectare. Nine of them (the exception being Teófilo Otoni) increased their average coffee productivity. Seven regions had an increase above $20 \%$, of which three had an increase above $70 \%$.

In addition to the regions already mentioned, others that were not included in low-low clusters also had significant increases in productivity. Conselheiro Lafaiete, Além Paraíba, Janaúba, São João del Rei, Montes Claros and São João Nepomuceno-Bicas increased productivity by more than $100 \%$ from 2002 to 2017 . 
On the other hand, in addition to this increase of productivity in many regions, there was a second kind of movement: some regions with small production but high productivity stopped their production. Regions whose production was concentrated in a few cities help to understand the difference between the scenarios before and after 2010. The immediate region of São Francisco was characterized as a region of high productivity from 2002 to 2009, sharing borders with the regions of Pirapora and Unaí, which fit into the high productivity group in every year. However, in the region of San Francisco, only one of its six cities was a producer and from 2010 on its productivity became low and it stopped producing coffee altogether after 2012. In this manner, a high-high spatial pattern turned into a high-low one.

A similar case is that of the immediate region of Pirapora, which was in the high productivity group in 12 of the 16 years. One of its neighboring regions, Januária, had only three municipalities producing coffee in 2002, reducing to two between 2003 and 2005, one from 2005 to 2009 and stopping coffee production completely from 2010 on. Thus, in a few years, a neighborhood pattern that was classified as high-high became high-low thereafter.

Figure 3 - LISA maps to productivity of immediate geographic regions, 2002 to 2017
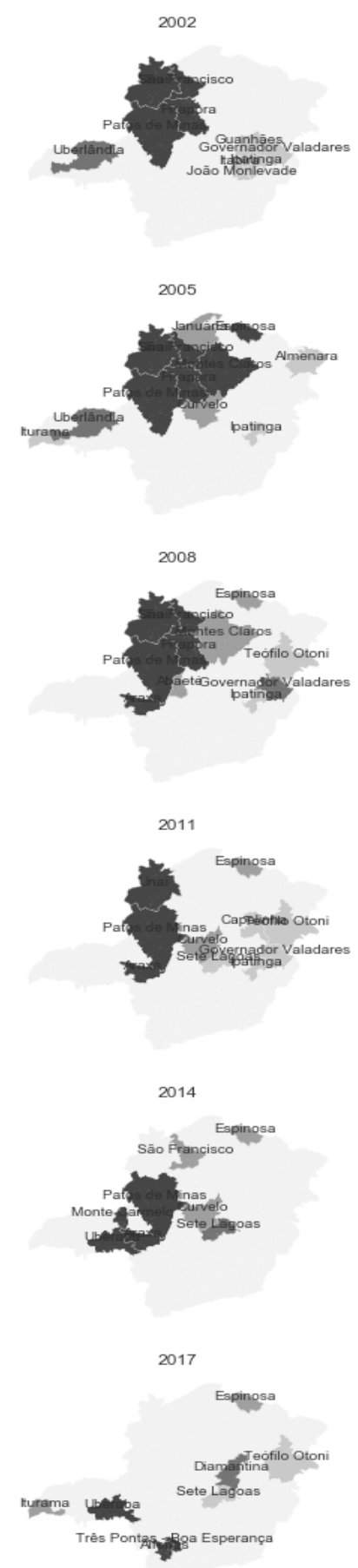


In the immediate region of Curvelo, in 2002, three municipalities produced coffee. Nonetheless, as of 2003, only one was still producing and what stopped from 2012 onwards. The region shares borders with two regions that showed high productivity in almost every year (Divinópolis and Pirapora) and had above average productivity in the years 2006, 2008 and 2009. Therefore, this is another example of high-high spatial pattern becoming a high-low one.

A common feature of the mentioned municipalities that stopped producing coffee is a small harvested area throughout the period, generally less than 100 hectares. This suggests that the previously seen overall tendency to reduce the harvested area in the state comes from the extinction of production in municipalities (and consequently regions) whose total output was already small, leading to the concentration in municipalities and regions with greater harvested area.

A third movement was the sustainment or increase in productivity in regions with large coffee production and that were already highly productive, such as Alfenas, Manhuaçu, Passos and Poços de Caldas.

In summary, three trends were observed from 2002 to 2017: (a) increased productivity in regions with large harvested area but low productivity, such as Patrocínio, Caratinga and Campo Belo; (b) abandonment of (or great reduction in) production in regions with small harvested area, even in some of those which had high productivity in some years, such as the regions of San Francisco, Espinosa and Curvelo; and (c) sustainment or increase in some regions with large harvested areas and already high productivity.
Permeating these trends is the spreading of high productivity through contiguity mentioned in the beginning of this section. The regions with higher productivity in the first years influenced positively their neighbors with lower productivity, a movement that has repeated itself over the years, increasing the average productivity in the state. This result was also found by Almeida et al. (2006) studying the microregions of Minas Gerais between 2000 and 2004 and Teixeira and Bertella (2015) analyzing the same microregions but between 1997 and 2006. Given the influence of regions with higher productivity over those with lower productivity, the result was a tendency of homogenization of productivity throughout the state.

\section{Concluding remarks}

This paper examined the spatial distribution of coffee productivity in Minas Gerais between 2002 and 2017 , including the presence of spatial patterns (spatial clusters and outliers). Positive spatial autocorrelation, measured by Moran's $I$, was observed in 9 of the 16 years under consideration. However, it was largely restricted to the first half of those years, when the measure was statistically significant in all of them. The maps of the local Moran's I for the immediate regions show the existence of local clusters of high productivity, but also its declining throughout the years.

In general, the regions with small harvested areas of coffee tended to leave the market, even when they have high productivity. Also, regions with large harvested areas tended to increase their productivity, even those with historically low productivity levels. Therefore, from 2002 to 2017, it was observed a homogenization of coffee productivity in Minas Gerais, converging to values close to $30 \mathrm{bags} / \mathrm{ha}$.

\section{References}

Almeida, E. 2012. Econometria espacial aplicada. Campinas, Alínea.

Almeida, E.; Pacheco, G. O.; Patrocínio, A. P.; Dias. S. M. 2006. Produtividade do café em Minas Gerais: uma análise espacial. Anais do XLIV Congresso Brasileiro de Economia e Sociologia Rural, Fortaleza, CE, Brasil. Disponível em: https://bit.ly/3gxorl8.

Anselin, L. 1996. Interactive Techniques and Exploratory Spatial Data Analysis. Disponível em: https://bit.ly/386MT9x.

CONAB. Companhia Nacional de Abastecimento. Acompanhamento da safra brasileira de café, v. 5, safra 2018. Brasília-DF. Disponível em: https://www.conab.gov.br/info-agro/safras/cafe.

Instituto Brasileiro de geografia e Estatística - IBGE. 2017. Divisão Regional do Brasil em Regiões Geográficas Intermediárias e Regiões Geográficas Imediatas: 2017. Rio de Janeiro. Disponível em: https:// bit.ly/2W18gTV.
2019. Produção agrícola municipal. Sistema IBGE de Recuperação Automática - SIDRA, Tabela 1613, 2019. Disponível em: https://sidra.ibge.gov.br/tabela/1613.

International Coffee Organization - ICO. 2018. Total production by all exporting countries. Disponível em: https://bit.ly/39YPSDt.

Neves, M.; Luiz, A. 2006. Distribuição espacial da cultura do café no estado de São Paulo. Boletim de Pesquisa e Desenvolvimento. Jaguariúna: Embrapa Meio Ambiente. Disponível em: https://bit. ly/3gzNjZR.

Souza, R.; Perobelli, F. 2007. Diagnóstico espacial da concentração produtiva do café no Brasil no período de 1991 a 2003. Revista de Economia e Agronegócio, v. 5, n. 3: 353-377. Disponível em: https:// bit.ly/2W2ItKY.

Teixeira, R.; Bertella, M. Distribuição espaço-temporal da produtividade média do café em Minas Gerais: 1997-2006. Análise Econômica, ano 33 , n. 63, 2015, p. 275-299. 